\title{
VICE PRESIDENT TASKS AND AUTHORITIES IN THE CONSTITUTIONAL SYSTEM OF THE REPUBLIC OF INDONESIA UNDER 1945 CONSTITUTION
}

\author{
Melan Yusuf Nomleni \\ Program Pascasarjana Ilmu Hukum Universitas Nusa Cendana Kupang \\ E-mail:Jusufnomleni@gmail.com
}

\begin{abstract}
The amendment of Constitution has not met the the life of the nation's demand, one of which is the of the tasks and authorities of the Vice President. This sparks multiple interpretations on the role and its legal implications toward the responsibility over the Vice President tasks and. The results show several reasons underlying obscurity of the tasks and authorities regulation of the Indonesian Vice President stated in 1945 Constitution, among which is the Indonesian governance. The obscure regulation of the Vice President tasks and authorities affects on his/her responsibility. Hence, the clear regulation related to the tasks and authorities of the Vice President as President Assistant in performing state governance is required.
\end{abstract}

Keywords: regulation, Vice President, authorities

\begin{abstract}
Abstrak
Amandemen Undang-Undang Dasar yang telah dilakukan belum memenuhi tuntutan kebutuhan dalam kehidupan berbangsa dan bernegara, salah satunya adalah pengaturan mengenai tugas dan wewenang Wakil Presiden. Hal ini menimbulkan multitafsir terhadap peran dan implikasi hukumnya terhadap tanggung jawab atas tugas dan wewenang Wakil Presiden. Hasil kajian menunjukkan alasan yang mendasari ketidakjelasan pengaturan tugas dan wewenang Wakil Presiden Republik Indonesia dalam UUD 1945, di antaranya adalah sistem pemerintahan yang dianut negara Republik Indonesia. Ketidakjelasan pengaturan tugas dan wewenang Wakil Presiden berimplikasi pada pertanggung-jawaban-nya. Atas dasar itu perlu pengaturan terkait dengan tugas dan wewenang Wakil Presiden sebagai pembantu Presiden dalam melakukan kekuasaan pemerintahan negara.
\end{abstract}

Kata kunci: pengaturan, Wakil Presiden, wewenang

\section{Introduction}

State Institution was established to perform its tasks and authorities. Among the state istitutions as of state administratives, there is executive body which is commonly known as the presidential institution. This insititution, according to 1945 Constitution, contains two (2) positions, the President and the Vice President.

The Indonesian constitution does not regulate the authority of the Vice President in conducting state tasks if the president is absent. The President's high power can be understood as a weakness of 1945 Constitution. ${ }^{1}$ That condi-

Muhammad Fauzan, “Kewenangan Mahkamah Konstitusi Dalam Proses Impeachment Presiden Menurut Sistem Ketatanegaraan Republik Indonesia", Jurnal Dinamika Hukum, Vol. 11 No. 1, January 2011, Purwokerto: Faculty of Law Universitas Jenderal Soedirman, page 72. tion raises some constitutional problems, for example, when the President was still abroad and in the country there was an emergency issue that must be resolved immediately without waiting for the President's arrival.

There are many unresolved and unexplanable constitutional issues that occur. One of them is the Decree (SK) No. 1 of 2004 on the Formation of the National Team for Aceh Disaster Management issued by Vice Precident during the reign of Susilo Bambang Yudhoyono and Jusuf Kalla to set up National Coordination Disaster Management of Aceh and North Sumatra. The Decree leads many critics considering it as unclear and legal basis absence. The former President Abdurrahman Wahid claimed that the decree signing exceeded the authority of the 
Vice President. The State Secretary at that time, Yusril Ihza Mahendra said that from a technical point of law, the issue of the Vice President's Decree is incorrect. Yusril said that the Decree signed by Vice President Jusuf Kalla should be the Decree of Head of the National Coordinating Agency for Disaster Management and Refugees, which happened that the Vice President Jusuf Kalla was as Chairman of the National Coordination Board which has own responsibility and requires legal protection cope with such disasters. ${ }^{2}$ This raises a problem because there are some people who justify the decree yet the rest question on the legal basis and the authority of the Vice President in issuing the Decree.

Referring to the various constitutional issues occurred related to the role of the Vice President, then this paper will discuss the regulation as well as the implications of the responsibility over the Vice President tasks and authorities as stated by 1945 Constitution.

\section{Discussion}

\section{The Vice President Tasks and Authorities as stated by 1945 Constitution}

The amendment of 1945 Constitution has taken four times which brought a fundamental transformation related to the constitutional system of the Republic of Indonesia. The existence of major state institutions changed indicated by the dismissal and establishment of new state institutions. $^{3}$ This is considered as fruitful attempts yet some unsatisfying things remain including the reform of the executive agency. The President was given clear and broad regulation related to the tasks and authorities in running the government, but not for the position of Vice President.

2 Sapto P, 12 January 2005, "Yusril: SK Wapres Keliru dari Teknis Perundang-undangan", available in the website http://www.tempo.co/read/news/2005/01/12/0554825 /Yusril-SK-Wapres-Keliru-dari/Teknis-Perundangundangan, accessed on 20 Februari 2015.

3 Winahyu Erwiningsing, "Mahkamah Konstitusi (Telaah Terhadap Putusan Mahkamah Konstitusi Dalam Reformasi Hukum)", Jurnal Ilmu Hukum, Vol. 9 No. 1, March 2006, Surakarta: Faculty of Law Universitas Muhammadiyah Surakarta, page 89.
The constitution regulation indicates that the tasks and authorities of the Vice President are united with the President's because it is a unity institution. Ideally, the Vice President as one of public officials is able to perform his task independently. However, the 1945 Constitution does not regulate strict rules regarding the authority of the Vice President as a separate office. This raises the question, how an important constitutional office in the country is not explicitly given the authority in the Constitution. When the Vice President conducts something or act on their own initiative (not delegated task of the President) that are beneficial to the interests of the state on behalf position, was it an inconstitutional? On the other hand, the Vice President as one of the constitutional positions is responsible for the people welfare.

This raises multiple interpretations to the position of the Vice President, but the ambiguity of these positions must have its own reason. Accordingly, the author studies three (3) aspects of the parameters or referrence to each formulation step and the amendment of articles of 1945 Constitution comprising the philosophical aspect, political aspect and the juridical aspect.

\section{Phylosophical Aspect}

Pancasila as the philosophy of the Indonesian nation implies that every aspect of national, social and state life should be based on the values and principles embedded in Pancasila as the reflection of the culture and experience of the Indonesian nation. It evolved from the nation's efforts to solve essential issues concerning basic meaning of Indonesian life.

In regard to the tasks and authorities of the Vice President in the Constitution, Pancasila has regulated deliberation-based governance and good cooperation among state administratives. Thus, the vice president shall cooperate with the President besides fulfilling the requirement as a candidate for Vice President by law. It aims that in case of problems in the country, the President and Vice President as one agency can cooperate to reach a consensus in decisionmaking process to resolve any problem. Particu- 
larly, if the tasks and authorities of the Vice President are set separately, the Vice President more focuses on his tasks and responsibilities. It may raise potential dispute and inharmonious relationship between the President and the Vice President.

Moreover, Pancasila as the philosophy of Indonesia expains that the state administrators must have determination and commitment to achieve the goals and ideals of the Indonesian nation regardless the inperfect formulation of 1945 Constitution. High commitment and passion should be possessed by the state administrators.

\section{Juridical Aspects}

The practice of government implementation based on law is somehow insufficient since there will always be weaknesses in written constitution. For insance, the provisions stating that further regulated by law. In fact there are some provisions which are not followed by the further regulations.

Provisions which contains norms of concrete duties of the Vice President cannot be found in the constitution. 1945 Constitution only provides rules regarding the authority of the President as head of state that has a prerog-atives or privileges. Those rights consist of im-plementation of Article 10, Article 11, Article 12, Article 13, Article 14 and Article 15 of the 1945 Constitution. ${ }^{4}$

Obscure regulation of tasks and authorities of the Vice President is also caused by the ambivalent position of Vice President in the constitution. This is in line with the statement of Bagir Manan and Magnar ${ }^{5}$ that there are two possibilities regarding the position of Vice President. First, an equal position with the president. This possibility can be identified by Judicial approach to Article 6 paragraph (2), Article 7, Article 8 and Article 9 of the 1945 Constitution.

4 Solikhatun Septia Pradini, "Analisis Yuridis Kekuasaan Presiden Dalam Membentuk Undang-Undang Sebelum dan Sesudah Amandemen UUD 1945", Jurnal Citizenship, Vol. 1 No. 1, July 2011, Yogyakarta: Universitas Ahmad Dahlan, page 4.

5 Bagir Manan and Kuntana Magnar, 1997, Beberapa Masalah Hukum Tata Negara Indonesia, Bandung: Alumni, page 22.
Based on this approach, it concludes that there is no hierarchical relationship between the President and the Vice President. The second possibility, that the position of Vice President is under the President (not equal). It can be seen through the interpretation of Article 4 (2) related to Article 5 of 1945 Constitution of the Republic of Indonesia, that the President is the highest level State officer which brings its all consequences of governance responsibilities regarding that the Vice President functions as an assistant of the President who determines his/ her tasks and authorities.

\section{Political Aspects}

The provisions of Article 4 paragraph (1) of 1945 Constitution shows that Indonesia applies presidential governmental system. The advantage of this system assures the stability of the government. This system can be practiced by implementing multi-party system which can accommodate the map configuration of political forces in society regardless the flaws.

Indonesian presidential system is different from other countries of similar governmental system; President and vice president of the same party will lead the mission using the same political platform. The interests of the executive branch can be minimized so that the wheels of government runs smoothly. Indonesia with its multi-party system which opens for coalition is in accordance with the provisions of Article 6A paragraph (2) 1945 Constitution. Different parties will automatically bring different political interests as with the President and the Vice President. ${ }^{6}$

Political gridlock may occur at any time during the implementation of state governance with a presidential system accompanied multiparty system. Thus to prevent it, President and the elected Vice President often must inevitably establish a "forced" cooperation with various political parties with different political agenda. ${ }^{7}$

6 Charles Simabura, "Akuntabilitas Rekruitmen Calon Anggota DPRD Sebagai Wujud Kedaulatan Rakyat”, Jurnal Konstitusi, Vol. 2 No. 1, June 2009, Jakarta: Constitutional Court of The Republic of Indonesia, page 14.

7 Bayu Dwi Anggono, "Perspektif Konstitusi Indonesia pada Kerjasama Partai Politik dalam Pemilihan Presiden 
Regarding to this, the division of tasks between the President and Vice President who practiced during the reign of Susilo Bambang Yudhoyono (SBY) and Jusuf Kalla (JK), based on a political agreement on the political, security and socio-economic scope. However, this task distribution is more based on a political deal between the two before taking the position of the President and the Vice President. Hence it becomes inevitable if the two figures have different opinion. Given the conditions, it would raise policy gap if the task of the Vice President is set separately from the President.

Instead of three (3) of the above-mentioned aspects, the Indonesian government system causes the Vice President has no constitutional authority in governance, namely the presidential system ${ }^{8}$, in which the highest executive power in the hands of President ${ }^{9}$.

Any acts of government and/or citizen should have a normative basis. This construction refers to Article 1 (3) of 1945 Constitution that Indonesia is a state of law $^{10}$. It is explicitly stated that the system of government was held based on the law not power. ${ }^{11}$ Law is a source as well as limit of power so it cannot be justified when the power is used as a tool for dictatorship. The principle of legality is a key principle that serves as the basis of governance implementation. Thus, the obscure regulation of the Vice President tasks and authority is proven

dan Wakil Presiden", Jurnal Pandecta, Vol. 9 No. 1, January 2014, Semarang: Universitas Negeri Semarang, page 94.

8 Bambang Hermanto, "Presiden Dan Pemerintahan Presidensial", Jurnal Ilmiah Abdi Ilmu, Vol. 3 No. 2, December 2010, Medan: Faculty of Law UNPAB, page 444-445.

9 Shinta Agustina, "Akibat Hukum Pengabaian Rekomendasi DPR Oleh Presiden (studi Yuridis Komparatif Terhadap Akibat Hukum Pengabaian Rekomendasi DPR Dalam Kasus Penghilangan Aktivis)", Jurnal Konstitusi, Vol. 1 No. 1, November 2012, Jakarta: Constitutional Court of The Republic of Indonesia, page 30.

10 Eko Noer Kristiyanto, "Pemakzulan Presiden Republik Indonesia Pasca Amandemen UUD 1945”, Jurnal Rechtsvinding, Vol. 3 No. 2, December 2013, Jakarta Timur: Media Pembinaan Hukum Nasional, page 334.

11 Maruar Siahaan, "Uji Konstitusionalitas Peraturan Perundang-Undangan Negara Kita: Masalah dan Tantangan", Jurnal Konstitusi, Vol. 7 No. 4, August 2010, Jakarta Pusat: Constitutional Court of The Republic of Indonesia, page 10; Kartono, "Politik Hukum Judicial Review Di Indonesia”, Jurnal Dinamika Hukum, Vol. 11 February 2011 Special Edition, Purwokerto: Faculty of Law Universitas Jenderal Soedirman, page 20. when the Vice President acts anything on behalf of his/her position beyond which regulated in laws is considered violating the law. Authority possessed by government institutions in performing their duties, holding or issuing a decree arrangement is always based on the authority derived from the attributive, delegative and mandatory constitution.

First, Attribution. Attribution is the authority to make decisions (Besluit) which is directly based on law. Article 4 (2) of 1945 Constitution determined "In conducting his/her duties, President is assisted by a Vice President". It means any form of assistance given by the Vice President to President in running the government "can be" understood as an attributive authority of the Vice President by the Constitution.

The word "can be" above given shows that the authority is abstract because the Constitution does not explain the extent of the assistance. The Vice President has no authority to regulate and decide because the tasks of the Vice President is to assist the President in the administration of state government so it cannot be said that, Vice President with the attributive authorities involve in making decision (legal acts), since the decision maker is President.

Second, Delegation. Delegation is the transfer of governmental authority from one governing organs to others. The authority that has been delegated becomes the authority itself, so the responsibility is on the delegates. In this regard, if President delegates state duties to the Vice President, the Vice-President acts as Vice President not President.

Considering the source of the authority of the presidency is the Constitution, then there is no legal reference to delegate President's constitutional authority to the Vice President. This becomes a problem when President is temporarily abscense either for health reasons or were abroad. There are no rules of the legal basis the delegation of tasks from the President to the Vice President. Yet practically the delegation of tasks to the Vice President by the President are usually given in the form of a Presidential Decree. The legal basis for such delegation also 
uses the Presidential Decree. This means that President has no duty to delegate the task to the Vice President in case of President temporarily abscense.

Third, Mandate. Theoretically, mandate exerts no transference in the sense of empowerment but the mandatary acts on behalf of the mandator. The mandatary appoints other officials to act on behalf of the mandatory. Related to the presidencial institution, the responsibility and accountability remains on President if man-date from President is given to the Vice Presid-ent to perform certain tasks.

The above description indicates that the forms of assistance given by the Vice President to the President can be understood as an attributive authority of constitutional Vice-President yet the regulation is still abstract so that the tasks and authority of the concrete in terms of assistance occurs when the President gave the delegation or mandate.

Referring to the material described above, it can be concluded that as the assistant of President to carry out state duties either on its own initiative or at the request of President, is still dependent on the delegation of powers from President because the Vice President has no significant constitutional authority.

\section{Legal Implications to the Responsibility over} the Vice President Tasks and Authorities

The Constitution as the source of power state institutions also acts as a limit so that their power do not exceed the given authority. Later, the use of power by officials of state institutions must be accountable juridically. ${ }^{12}$

Amendment to the 1945 Constitution has changed the Indonesia state system fundamentally; MPR is no longer a source of highest state power that distributes power to other state institutions, ${ }^{13}$ including has no longer the mono

12 Bachtiar Baital, "Pertanggungjawaban Penggunaan Hak Prerogatif Presiden Di Bidang Yudikatif Dalam Menjamin Kemerdekaan Kekuasaan Kehakiman”, Jurnal Cita Hukum, Vol. 1 No. 1, June 2014, Jakarta: Faculty of Sharia and Law, Universitas Islam Negeri (UIN) Syarif Hidayatullah, page 33-34.

13 Luthfi Widagdo Eddyono, "Penyelesaian Sengketa Kewenangan Lembaga Negara oleh Mahkamah", Jurnal Kons- power to appoint the President and the Vice President but the positions of President and the Vice President has been more democratically elected directly by the people so that the President and the Vice President shall submit the accountability report to the Indonesian people who choose them.

The provisions of Article 4 paragraph (1) of 1945 Constitution has underlined that "President of the Republic of Indonesia holds the power of government in accordance with the Constitution." Particularly, the authorities and responsibilities of government in the hand of one person that is President. The rising question is dealing with its assistance duty, should the Vice President be legally responsible? then, whom the Vice President is responsible for since there is no formal provision explicitly set up. President may ask Vice President resposibility on the implementation of the delegated tasks but not in terms of direct accountability to the people on government administration.

This is contrary to the principle of democracy which requires transparency of government, in the sense that there is no irresponsible authority. Therefore, the Vice President as a constitutional position must prove his/her accountability. The principle of accountability, in good governance requires public accountability for any activity undertaken by the government. However, the obscure forms and to whom the accountability of the Vice President is given indicate the negative implications of obscure regulation tasks and authority of the Vice President of the laws and regulations in Indonesia, as a basis for assessing the performance of the Vice President as an office constitutionally elected directly by the people and therefore have greater legitimacy in the sense of strengthening the presidential system.

\section{Conclusion}

The reasons underlying the obscure regulation of the Vice President tasks and authorities the in the 1945 Constitution (both pre and

titusi, Vol. 7 No. 3, June 2010, Jakarta: Constitutional Court of The Republic of Indonesia, pages 5-6. 
post amendment) is as follows: first, the philosophical aspects, because Pancasila has explained good governance on the basis of deliberation and good cooperation among state government leaders; second, the judicial aspect, that the state of law doctrine, the real leader is not a person/figure but the law is seen as a system; and third, the political aspects, namely Indonesia employs multiparty system so there are opportunities for executives pair coming from different parties. Automatically political interests behind the President and Vice President would be different. It potentially sparks interpretation and anxiety if the tasks and authorities of Vice President determined by law is separate from the President since leader-ship or government dualism would not run along and in line on the basis of political interests of President and Vice President.

The obsure regulation of Vice President tasks and authority in the 1945 Constitution has implications for the emergence of various excesses or friction responsibility in the administration of state government and also has implications for the capacity and competence strengthening as well as institutions in state system.

\section{Suggestion}

People's Consultative Assembly necessarily amend the 1945 Constitution by adding the substance associated with the tasks and authorities of the Vice President as the President assistant in running state administration. To avoid legal implications in the state system as outlined in conclusion, it is suggested that the government in this case the President and the House of Representatives should establish a Law regarding Presidential Institution which governs the tasks and authorities of the President and its relationship with Vice President in the administration of state government. By doing so, the division tasks between the President and Vice President are clear by refering to Pancasila as the basic philosophy of the Indonesian nation, the constitution as the basis and juridical instrument that assure assurance or legality of acts by considering the political aspects, both at formation and implementation to prove democratization.

\section{References}

Agustina, Shinta. “Akibat Hukum Pengabaian Rekomendasi DPR Oleh Presiden (studi Yuridis Komparatif Terhadap Akibat Hukum Pengabaian Rekomendasi DPR Dalam Kasus Penghilangan Aktivis)". Jurnal Konstitusi. Vol. 1 No. 1. November 2012. Jakarta: Constitutional Court of The Republic of Indonesia;

Anggono, Dwi Bayu. "Perspektif Konstitusi Indonesia pada Kerjasama Partai Politik dalam Pemilihan Presiden dan Wakil Presiden". Jurnal Pandecta. Vol. 9 No. 1. January 2014 Edition. Semarang: Universitas Negeri Semarang;

Baital, Bachtiar. "Pertanggungjawaban Penggunaan Hak Prerogatif Presiden Di Bidang Yudikatif Dalam Menjamin Kemerdekaan Kekuasaan Kehakiman". Jurnal Cita Hukum. Vol. 1 No. 1. June 2014 Edition Jakarta: Faculty of Sharia and Law Universitas Islam Negeri (UIN) Syarif Hidayatullah;

Eddyono, Luthfi Widagdo. "Penyelesaian Sengketa Kewenangan Lembaga Negara oleh Mahkamah". Jurnal Konstitusi. Vol. 7 No. 3. June 2010 Edition. Jakarta: Constitutional Court of The Republic of Indonesia;

Erwiningsing, Winahyu. "Mahkamah Konstitusi (Telaah Terhadap Putusan Mahkamah Konstitusi Dalam Reformasi Hukum)". Jurnal Ilmu Hukum. Vol. 9 No. 1. March 2006. Surakarta: Faculty of Law Unversitas Muhammadiyah Surakarta;

Fauzan, Muhammad. "Kewenangan Mahkamah Konstitusi Dalam Proses Impeachment Presiden Menurut Sistem Ketatanegaraan Republik Indonesia". Jurnal Dinamika Hukum. Vol. 11 No. 1 January 2011. Purwokerto: Faculty of Law Universitas Jenderal Soedirman;

Hermanto, Bambang. "Presiden Dan Pemerintahan Presidensial". Jurnal Ilmiah Abdi Ilmu. Vol. 3 No. 2. December 2010. Medan: Faculty of Law UNPAB;

Kartono. "Politik Hukum Judicial Review Di Indonesia". Jurnal Dinamika Hukum. Vol. 11. February 2011 Special Edition. Purwokerto: Faculty of Law Universitas Jenderal Soedirman; 
Kristiyanto, Eko Noer. "Pemakzulan Presiden Republik Indonesia Pasca Amandemen UUD 1945". Jurnal Rechtsvinding. Vol. 3 No. 2. December 2013. Jakarta Timur: Media Pembinaan Hukum Nasional;

Manan, Bagir dan Magnar Kuntana. 1997. Beberapa Masalah Hukum Tata Negara Indonesia. Bandung: Alumni;

P, Sapto. 12 January 2005 "Yusril: SK Wapres Keliru dari Teknis Perundang-undangan”. tersedia di website http://www.tempo. $\mathrm{co} / \mathrm{read} / \mathrm{news} / 2005 / 01 / 12 / 0554825 /$ Yusr il-SKWapres-Keliru-dari-Teknis-

Perundang-undangan. accessed on 20 February 2015;

Pradini, Septia Solikhatun. "Solikhatun Septia Pradini. "Analisis Yuridis Kekuasaan Presi- den Dalam Membentuk Undang-Undang Sebelum dan Sesudah Amandemen UUD 1945". Jurnal Citizenship. Vol. 1 No. 1. July 2011. Yogyakarta: Universitas Ahmad Dahlan;

Siahaan, Maruar. "Uji Konstitusionalitas Peraturan Perundang-Undangan Negara Kita: Masalah dan Tantangan". Jurnal Konstitusi. Vol. 7 No. 4. August 2010. Jakarta Pusat: Constitutional Court of The Republic of Indonesia;

Simabura, Charles. "Akuntabilitas Rekruitmen Calon Anggota DPRD Sebagai Wujud Kedaulatan Rakyat". Jurnal Konstitusi. Vol. 2 No. 1. June 2009 Edition. Jakarta: Constitutional Court of The Republic of Indonesia. 